\title{
Intercomparison and Validation Exercises in the Southern Urals and the Kazakh Polygon
}

\author{
W. BURKART*, P. GOLOSHAPOV**, K. KÖNIG*, \\ S. MUNDIGL*, G.N. ROMANOV***
}

(Manuscrit reçu le 22 mai 1996, révisé le 15 décembre 1996, accepté le 10 janvier 1997)

ABSTRACT The military nuclear activities in the former Soviet Union led to unique contaminations and resulted in high cumulative exposures. $A$ proper assessment is needed for mitigation and for the further development of radiation protection. Environmental samples from areas affected by large radioactive releases into the Techa river starting in 1948 and by fall-out from the explosion of a tank containing high level waste in 1957 , were independently analysed by two Russian groups and by our team in 1992-93. Soil, sediments, milk, and fish samples were split into three aliquots and analysed for ${ }^{90} \mathrm{Sr},{ }^{137} \mathrm{Cs}$ and plutonium. Soil values in areas accessible to the local population were up to $16 \mathrm{kBq} \mathrm{kg}^{-1}$ for ${ }^{90} \mathrm{Sr}$, up to $26 \mathrm{kBq} \mathrm{kg}^{-1}$ for ${ }^{137} \mathrm{Cs}$ and up to $12 \mathrm{~Bq} \mathrm{~kg}^{-1}$ for ${ }^{239} \mathrm{Pu}$, respectively. Milk generally contained low levels ranging from $<1$ to $25 \mathrm{~Bq} \mathrm{~kg}^{-1}$ for ${ }^{90} \mathrm{Sr}, 1$ to $14 \mathrm{~Bq} \mathrm{~kg}^{-1}$ for ${ }^{137} \mathrm{Cs}$ and $<0.1 \mathrm{~Bq} \mathrm{~kg}^{-1}$ for plutonium. Pike from the Techa river, however, showed $15,000 \mathrm{~Bq} \mathrm{~kg}^{-1} 90 \mathrm{Sr}$. In 1993, 750 in vivo measurements of ${ }^{90} \mathrm{Sr} / 90 \mathrm{Y}$ were performed in individuals of communities situated downstream of Majak which had incorporated large activities of ${ }^{90} \mathrm{Sr}$ from using the Techa river as drinking water supply. To help validate a large body of Russian measurements, a transportable body counter which measures the scull content of ${ }^{90} \mathrm{Sr} /{ }^{90} \mathrm{Y}$ directly from high energy $\beta$ 's emitted from the front of the head and also indirectly via Bremsstrahlung was developed. Although the highest activities $(37 \mathrm{kBq})$ were found in persons having lived at the river Techa during the early releases, considerable ${ }^{90} \mathrm{Sr}$ contaminations, often accompanied with elevated ${ }^{137} \mathrm{Cs}$ burdens, were also found in younger persons indicating recent ingestion. Chronic and recent contaminations will add to the uncertainties involved in the assessment of bone marrow doses from ${ }^{90} \mathrm{Sr}$ as a crucial element in dose reconstruction for the Techa river cohort. A first visit to the medical school and health institutions in Semipalatinsk and to a village having been heavily contaminated by an atmospheric bomb test at the Polygon yielded sometimes contradictory information but indicated high cumulative exposures in several Kazakh settlements adjacent to the test site.

\footnotetext{
* Institute for Radiation Hygiene and Department for Radiation Protection of the Federal Office for Radiation Protection, Ingolstädter Landstr. 1, 85764 Oberschleißheim/München, Germany.

** Ural Research Institute for Radiation Medicine, Cheliabinsk, Russia.

*** Environmental Laboratory Majak (formerly ONIS), Cheliabinsk 65, Russia.
} 
Exercices d'intercomparaison et de validation dans l'Oural du Sud et le Polygone de Kazakh

RÉSUMÉ Dans l'ex-URSS, les activités nucléaires militaires ont conduit à des contaminations exceptionnelles; il en est résulté des expositions élevées, cumulées. Il est nécessaire d'effectuer une évaluation particulière pour l'optimisation et le développement futur de la radioprotection. En 1992-93, deux groupes russes et notre équipe ont mesuré, indépendamment, des échantillons de l'environnement provenant de zones ayant subi des rejets de radioactivité dans la rivière Techa depuis 1948, ainsi que les retombées de l'explosion d'un réservoir contenant des déchets d'activité élevée. Des échantillons de sols, de sédiments, de lait, de poissons, furent divisés en trois parties aliquotes; on y a analysé ${ }^{90} \mathrm{Sr}$, ${ }^{137} \mathrm{Cs}$ et le plutonium. Pour le sol, dans des zones accessibles à la population locale, les valeurs maximales étaient de $16 \mathrm{kBq} \mathrm{kg}^{-1}$ pour ${ }^{90} \mathrm{Sr}, 26 \mathrm{kBq} \mathrm{kg}^{-1}$ pour ${ }^{137} \mathrm{Cs}$ et $12 \mathrm{~Bq} \mathrm{~kg}^{-1}$ pour ${ }^{239} \mathrm{Pu}$. Dans le lait, les niveaux étaient généralement bas; ils étaient de moins de 1 à $25 \mathrm{~Bq} \mathrm{~kg}^{-1}$ pour ${ }^{90} \mathrm{Sr}$, de 1 à $14 \mathrm{~Bq} \mathrm{~kg}^{-1}$ pour ${ }^{137} \mathrm{Cs}$; ils étaient inférieurs à $0,1 \mathrm{~Bq} \mathrm{~kg}^{-1}$ pour le plutonium. Cependant, des brochets de la rivière Techa accusaient $15000 \mathrm{~Bq} \mathrm{kg-1}$ en ${ }^{90} \mathrm{Sr}$. En 1993, on a effectué 750 mesures in vivo de ${ }^{90} \mathrm{Sr} /{ }^{90} \mathrm{Y}$, sur des individus appartenant à des collectivités situées en aval de Majak ; ils avaient incorporé des activités importantes de ${ }^{90} \mathrm{Sr}$, car ils utilisaient la rivière Techa comme source d'eau potable. Afín d'aider à valider une grande partie des mesures effectuées par les Russes, nous avons mis au point un compteur corporel transportable; il mesure la concentration de ${ }^{90} \mathrm{Sr} / 90 \mathrm{Y}$ directement, à partir des rayons bêta de haute énergie émis par la partie avant de la tête ou, indirectement, à partir du rayonnement de freinage qu'ils produisent. Les personnes qui vivaient près de la rivière Techa durant les premiers rejets présentaient les activités les plus grandes $(37 \mathrm{kBq})$; cependant on a trouvé, chez des personnes plus jeunes, une contamination considérable en ${ }^{90} \mathrm{Sr}$, souvent accompagnée de charges importantes en ${ }^{137} \mathrm{Cs}$ : c'était le signe d'une ingestion récente. Les contaminations, chronique ou récente, s'ajoutent aux incertitudes de la détermination des doses de ${ }^{90} \mathrm{Sr}$ dans la moelle osseuse, pour former l'élément crucial de la reconstitution des doses pour la cohorte de la rivière Techa. Nous avons tiré des informations parfois contradictoires d'une première visite à l'École de médecine et aux établissements sanitaires de Semipalatinsk, ainsi qu'à un village fortement contaminé par un essai nucléaire atmosphérique, sur le Polygone ; cependant, elles indiquaient des expositions élevées, cumulées, dans plusieurs agglomérations de Kazakhs, contiguës au site d'essai.

\section{Introduction}

Apart from the large scale contaminations from the reactor accident of Tschernobyl-4, the successor states of the Soviet Union are also exposed to considerable environmental contaminations from the nuclear weapons program. Particularly in the region between Cheliabinsk and Ekatarinenburg in the South Ural, the beginning of the bomb production caused heavy occupational exposures of up to 1 Gy per year from the reprocessing of plutonium and discharges of significant activities of fissile material $\left(10^{17} \mathrm{~Bq}(3 \mathrm{MCi})\right)$ into the Techa river and the lakes in its catchment basin. Communities situated downriver, which were supplied with drinking water from the Techa in the beginning 
of the $50 \mathrm{~s}$, received doses to the bone marrow of up to $3 \mathrm{~Gy}$ (Akleyev and Lyubchansky, 1994), due to ${ }^{90} \mathrm{Sr}$ ingestions. High level waste was stored in large tanks (UNSCEAR, 1993). Due to the breakdown of cooling in such a tank in 1957, the explosion of a dried mixture of radioactive nitrate- and acetate salts (Kyshtym accident) caused a cigar-shaped contamination of $7 \times 10^{17} \mathrm{~Bq}(20 \mathrm{MCi})$ fission products, mainly ${ }^{144} \mathrm{Ce}(66 \%),{ }^{95} \mathrm{Zr} / 95 \mathrm{Nb}(25 \%)$, and ${ }^{90} \mathrm{Sr}(5.4 \%)$. Other exposures which, at present, are difficult to quantify occurred around the test sites of Semipalatinsk and Nowaja Semlja. Potential problems arise also from at least 100 subterranean nuclear explosions for peaceful purposes, i.e. mainly for the extraction and storage of natural gas, as well as from the accidental and deliberate sinking of decommissioned nuclear driven submarines.

German contributions centre on the screening of body burden in critical populations by whole body counting ( ${ }^{90} \mathrm{Sr}$ along river Techa, ${ }^{137} \mathrm{Cs}$ around Chernobyl), as a part of joint efforts to correlate human doses with health effects as a prerequisite to derive risk factors from chronic radiation exposures. For the quantitative estimation of organ doses from chronic exposure, it is necessary to validate and extend the large wealth of dosimetric and health data already collected in the Community of Independent States.

\section{Materials and methods}

The intercomparison measurements were performed jointly with two Russian environmental laboratories: Experimental line of Majak (ONIS) and the Ural Research Centre for Radiation Medicine (URCRM). In 1992, these intercalibration and intercomparison measurements were focused on radionuclide ${ }^{90} \mathrm{Sr}$, whereas in 1993 plutonium isotopes and ${ }^{137} \mathrm{Cs}$ were determined. Both measuring periods lasted about six weeks.

Because samples from Russia could not be taken to Germany, the Federal Office for Radiation Protection (BfS) had to take the necessary equipment for chemical sample preparation, for the determination of beta-particles from ${ }^{90} \mathrm{Sr}$ decay and for $\alpha$ - and $\gamma$-spectrometry from Munich to Cheljabinsk 65 in 1992 and again in 1993. An environmental measurement laboratory was installed at ONIS. BfS built up a low level measuring device with Geiger-Müller counters for the detection of beta-radiation from ${ }^{90} \mathrm{Sr}$ and two alphaspectrometers equipped with surface barrier detectors made of silicium and a multi channel analyser. At ONIS, the BfS installed all devices necessary for the radiochemical preparation of environmental samples. A van served both as a mobile unit to take samples, to measure dose rates, to perform in situ spectrometry and as a mobile gamma spectrometry laboratory. For the latter purpose, a high purity germanium detector was installed in a small lead shielding. Using an electric generator, this mobile laboratory operated independently of local power supplies. 
In 1992, about 70 environmental samples were taken and analysed for their ${ }^{90} \mathrm{Sr}$-content. Fewer samples were analysed for plutonium in 1993 because the samples required more time-consuming radiochemical preparation. Twentytwo plutonium analyses were performed. All these samples were also analysed for ${ }^{137} \mathrm{Cs}$ using gamma spectrometry. Analytical methods used by the three laboratories are described by Winkelmann et al. (1997).

Radiochemical methods and measuring instruments were compared first. For that purpose, the BfS prepared samples of plutonium, ${ }^{90} \mathrm{Sr}$ and ${ }^{137} \mathrm{Cs}$ each with different activities, by diluting standard solutions which were certified by the Physikalisch-Technische Bundesanstalt. These samples were treated like environmental samples: they were analysed after radiochemical preparation by the institutes involved. The maximum deviation of measured activity concentrations from the certified value was about $15 \%$. The radiochemical methods and the measuring instruments gave comparable results for the radionuclides considered. Note, however, that there were no potential confounders in these standard samples, as would be the case for environmental samples. Therefore, the main part of the intercomparison program focused on the analysis of environmental samples, i.e. soil, sediments, water, milk, potatoes and fish.

\section{Environmental measurements}

The intercomparison of environmental samples yielded a fair agreement among the three independent laboratories. For the measurement of plutonium, the Russian laboratories separated the plutonium isotopes radiochemically and then measured gross alpha emitters, whereby some impurities are included while the BfS performed alpha spectrometry. Therefore, the Russian method sometimes yielded higher values than those obtained by alpha spectrometry. The results of measurements of environmental samples are summarised in tables I to IV. For plutonium only nuclidspecific results are given.

Soil values in areas accessible to the local population ranged from $10 \mathrm{~Bq}$ $\mathrm{kg}^{-1}{ }^{90} \mathrm{Sr}$ at Krasny-Partizan up to $190 \mathrm{~Bq} \mathrm{~kg}^{-1}$ at Muslyumovo, some distance from the Techa river. The corresponding values for ${ }^{137} \mathrm{Cs}$ and ${ }^{239} \mathrm{Pu}$ ranged from $50 \mathrm{~Bq} \mathrm{~kg}-1$ to $460 \mathrm{~Bq} \mathrm{~kg}^{-1}$ and from $1 \mathrm{~Bq} \mathrm{~kg}^{-1}$ to $13 \mathrm{~Bq} \mathrm{~kg}^{-1}$ respectively. Approaching the Techa river, the situation changes rapidly. Soil samples taken at the Techa floodplain are contaminated with up to $16,000 \mathrm{~Bq} \mathrm{~kg}^{-1}{ }^{90} \mathrm{Sr}$, $26,000 \mathrm{~Bq} \mathrm{~kg}{ }^{-1}{ }^{137} \mathrm{Cs}$ and $13 \mathrm{~Bq} \mathrm{~kg}^{-1}$ plutonium. Techa sediment contained 30 $\mathrm{Bq} \mathrm{kg}-1$ plutonium, up to $40,000 \mathrm{~Bq} \mathrm{~kg}^{-1}{ }^{137} \mathrm{Cs}$ and $600 \mathrm{~Bq} \mathrm{~kg}^{-1}{ }^{90} \mathrm{Sr}$. Techa water, however, shows a lower contamination with $0.4 \mathrm{~Bq} \mathrm{~kg}^{-1}$ plutonium, 18 $\mathrm{Bq} \mathrm{kg}{ }^{-1}{ }^{90} \mathrm{Sr}$ and $0.6 \mathrm{~Bq} \mathrm{~kg}{ }^{-1}{ }^{137} \mathrm{Cs}$.

In table II, we added the measured dose rate at the sampling locations. The measured dose rates are comparable to those measured in Germany. On floodplains of the Techa river, however, the dose rate reaches values of 1.2 to $5 \mu \mathrm{Sv} / \mathrm{h}$. The meadow at the Techa river is not flooded by river water and dose rates there were comparable to those at other sampling sites. 
TABLE I

$\mathrm{Pu},{ }^{90} \mathrm{Sr}$ and ${ }^{137} \mathrm{Cs}$ intercomparison measurements of samples from the Techa river near Muslyumovo (1992: ${ }^{90} \mathrm{Sr}$; 1993: Pu and ${ }^{137} \mathrm{Cs}$ ).

Intercomparaisons expérimentales de $\mathrm{Pu},{ }^{90} \mathrm{Sr}$ et ${ }^{137} \mathrm{Cs}$, pour des échantillons provenant de la rivière Techa, près de Muslyumovo (1992 : ${ }^{90} \mathrm{Sr} ; 1993$ : Pu et $\left.{ }^{137} \mathrm{Cs}\right)$.

\begin{tabular}{|c|c|c|c|c|}
\hline Techa water & 0.08 & 0.28 & $7.4-18$ & $0.41-0.59$ \\
\hline Techa sediment & 0.95 & 33 & $420-610$ & $37,000-40,000$ \\
\hline \multicolumn{5}{|c|}{ Soil from Techa floodplain } \\
\hline First sample $0-10 \mathrm{~cm}$ & 0.23 & 9.7 & $4,700-5,600$ & $24,000-26,000$ \\
\hline Second sample $0.5 \mathrm{~cm}$ & 0.50 & 12 & $7,100-16,000$ & $18,000-21,000$ \\
\hline $5-10 \mathrm{~cm}$ & - & - & $6,200-12,000$ & $21,000-25,000$ \\
\hline $10-15 \mathrm{~cm}$ & 0.50 & 6.0 & $5,700-9,600$ & $3,300-3,900$ \\
\hline $15-20 \mathrm{~cm}$ & 0.23 & 1.7 & $5,500-9,600$ & $280-320$ \\
\hline $20-25 \mathrm{~cm}$ & 0.65 & 0.51 & $3,900-7,900$ & $300-350$ \\
\hline $25-30 \mathrm{~cm}$ & 0.12 & 1.2 & $340-790$ & 1,100 \\
\hline
\end{tabular}

Food products contained generally low levels of radioactivity. There were only few samples which showed elevated levels of activity and most of them were taken in the vicinity of the Techa river. Milk from private farms in Muslyumovo contained up to $25 \mathrm{~Bq} \mathrm{~kg}{ }^{-1}{ }^{90} \mathrm{Sr}$, compared to 1 to $5 \mathrm{~Bq} \mathrm{~kg}^{-1}$ measured in milk samples from other villages and from state dairy companies. This highly ${ }^{90} \mathrm{Sr}$ contaminated milk came from cattle that grazed along the Techa river and on the floodlands. The state dairy companies, however, collect milk from several locations and therefore these values do not show local effects.

Fish also contained high specific ${ }^{90} \mathrm{Sr}$ activities. In 1992, one fish sample (pike) from the Techa river contained $15,000 \mathrm{~Bq} \mathrm{~kg}^{-1}{ }^{90} \mathrm{Sr}$. In order to validate this result in 1993, a fish was divided in fish meat and bones. The analysis resulted in a specific ${ }^{90} \mathrm{Sr}$ activity of $330 \mathrm{~Bq} \mathrm{~kg}^{-1}$ in fish meat and $930 \mathrm{~Bq} \mathrm{~kg}^{-1}$ in fishbones. Potatoes from Krasny-Partizan were contaminated with $12 \mathrm{~Bq} \mathrm{~kg}^{-1}$ ${ }^{90} \mathrm{Sr}$. Plutonium analyses of food samples concentrated on milk. Measurements performed in 1993 yielded no activity above the detection limit of $0.1 \mathrm{~Bq} \mathrm{l}^{-1}$. Specific ${ }^{137} \mathrm{Cs}$ activities in milk ranged from 1.2 to $7.3 \mathrm{~Bq} \mathrm{~kg}^{-1}$. Potatoes from Muslyumovo contained $13 \mathrm{~Bq} \mathrm{~kg}^{-1}$ and the fish $43 \mathrm{~Bq} \mathrm{~kg}^{-1}{ }^{137} \mathrm{Cs}$. 
TABLE II

Pu, ${ }^{90} \mathrm{Sr}$ and ${ }^{137} \mathrm{Cs}$ intercomparison measurements of soil samples.

Intercomparaison expérimentale de $\mathrm{Pu},{ }^{90} \mathrm{Sr}$ et ${ }^{137} \mathrm{Cs}$ pour des échantillons de sol.

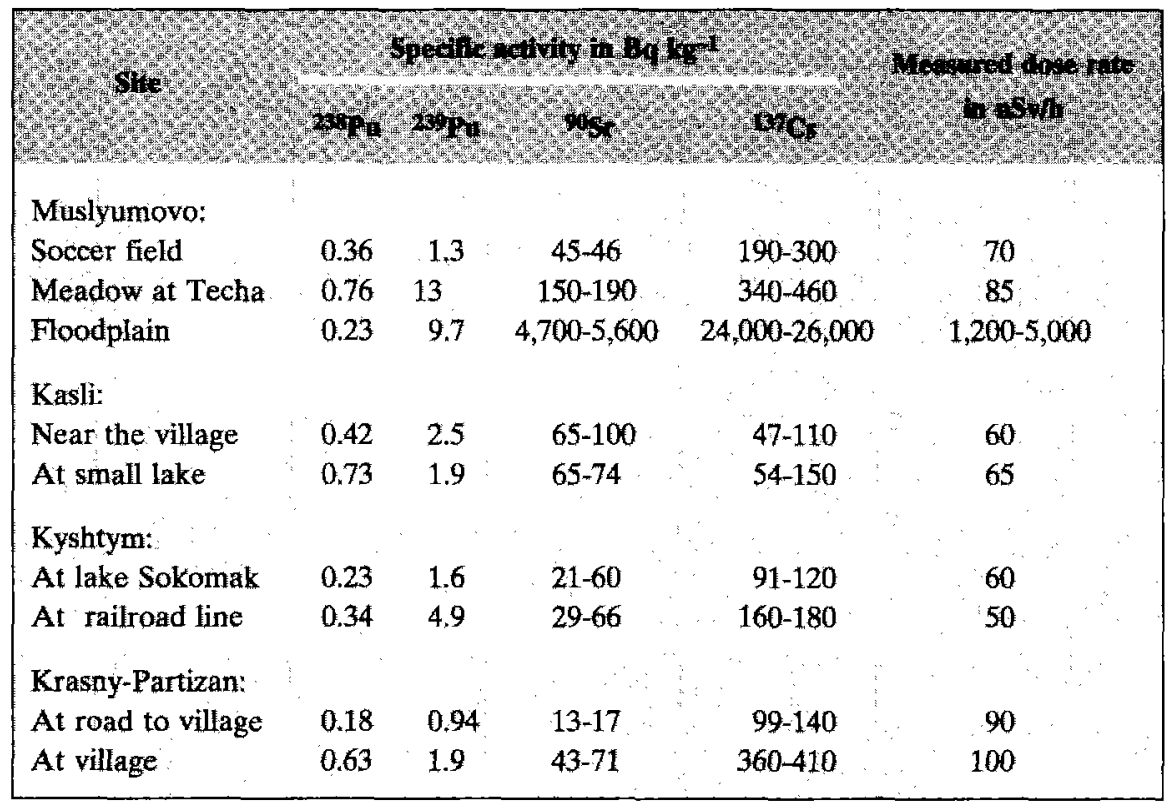

TABLE III

Pu, ${ }^{90} \mathrm{Sr}$ and ${ }^{137} \mathrm{Cs}$ intercomparison measurements of milk samples (1992: ${ }^{90} \mathrm{Sr}$; 1993: Pu and ${ }^{137} \mathrm{Cs}$ ).

Intercomparaison expérimentale de $\mathrm{Pu},{ }^{90} \mathrm{Sr}$ et ${ }^{137} \mathrm{Cs}$ pour des échantillons de lait (1992: ${ }^{90} \mathrm{Sr} ; 1993$ : Pu et $\left.{ }^{137} \mathrm{Cs}\right)$.

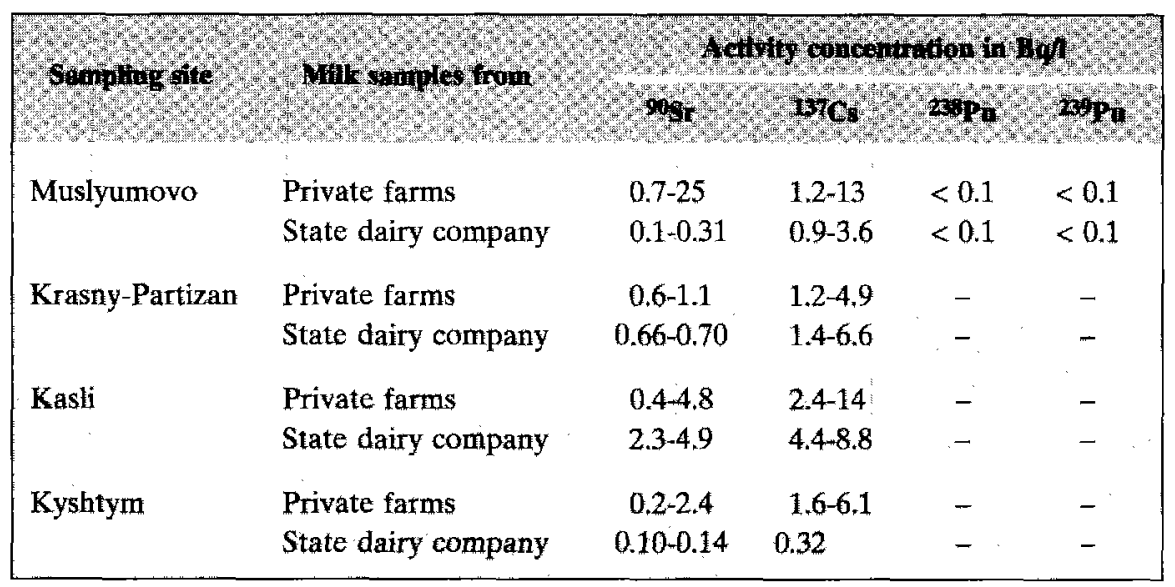


The results should be compared to typical values measured in Germany. Soil samples taken in Germany range from 0.5 to $5 \mathrm{~Bq} \mathrm{~kg}^{-1}{ }^{90} \mathrm{Sr}$ and 5 to $150 \mathrm{~Bq} \mathrm{~kg}{ }^{-1}{ }^{137} \mathrm{Cs}$, mainly from the Chernobyl accident in 1986 and from global nuclear weapons fallout. The corresponding values for milk are 0.1 to $3 \mathrm{~Bq}$ $\mathrm{kg}^{-1}{ }^{137} \mathrm{Cs}$ and 0.05 to $0.15 \mathrm{~Bq} \mathrm{~kg}-190 \mathrm{Sr}$, for potatoes 0.09 to $0.40 \mathrm{~Bq} \mathrm{~kg}^{-1}{ }^{137} \mathrm{Cs}$ and 0.04 to $0.27 \mathrm{~Bq} \mathrm{~kg}^{-1}{ }^{90} \mathrm{Sr}$. Drinking water contains a few millibecquerel per liter (Umweltradioaktivität, 1991).

TABLE IV

${ }^{90} \mathrm{Sr}$ and ${ }^{137} \mathrm{Cs}$ intercomparison measurements of food samples (1992 and 1993).

Intercomparaisons expérimentales de ${ }^{90} \mathrm{Sr}$ et ${ }^{137} \mathrm{Cs}$, pour des échantillons d'aliments (1992 et 1993).

\begin{tabular}{|c|c|c|c|}
\hline \multirow[t]{2}{*}{ Sampling site } & \multirow{2}{*}{ Sample } & \multicolumn{2}{|c|}{ Specife activity in Bq kg } \\
\hline & & $90 \mathrm{Sr}$ & $137 \mathrm{Cs}$ \\
\hline Muslyumovo & Fish: meat & 330 & 43 \\
\hline & bones & 930 & 43 \\
\hline & Whole fish (pike in 1992) & 15,000 & \\
\hline Muslyumovo & Drinking water & $<0.10-0.25$ & $<0.10$ \\
\hline Kasli & Drinking water & 0.02 & $0.10-0.40$ \\
\hline Muslyumovo & Potatoes & $2.2-6.2$ & $13-70$ \\
\hline Krasny-Partizan & Potatoes & $3.4-12$ & $13-54$ \\
\hline Kasli & Potatoes & $1.0-1.3$ & $11-26$ \\
\hline Kyshtym & Potatoes & $0.85-1.0$ & $14-31$ \\
\hline
\end{tabular}

\section{Direct whole body counting of incorporated ${ }^{90} \mathrm{Sr} / 90 \mathrm{Y}$}

To measure in the affected settlements, a mobile in vivo ${ }^{90} \mathrm{Sr}$ counter was developed which measures the high energy electrons of ${ }^{90} \mathrm{Sr} /{ }^{90} \mathrm{Y}$ decay directly on the forehead, Bremsstrahlung at the back of the head, and possible confounding radionuclides such as ${ }^{137} \mathrm{Cs}$ with germanium detectors directed towards the lower abdomen. Technical background information on the newly developed ${ }^{90} \mathrm{Sr}$ body counter is given by Wahl et al. (1996). Ultrasound measurements were performed on the forehead to account for the strong dependence of electron absorption on the thickness of the scalp. For intercomparison, 72 persons were measured jointly with the in vivo whole body counter of the Urals Research Institute of Radiation Medicine (Kozheurov, 1994b). Given the many difficulties involved in the direct ${ }^{90} \mathrm{Sr}$ determination in a human body and the different approach used in the two counters, the overall correlation was good. 
First results on inhabitants of the two most heavily affected non-evacuated villages Muslyumovo and Brodokalmak along the Techa river are shown in figure 1. As shown with a much larger data base by Kozheurov (1994a, b), the highest body burdens are found in age groups having had their bone growth peaking around 1950 , i.e. those born around 1935. Despite background differences found during the field measurements, the elevated levels for individuals born after 1954 indicate the existence of persistent incorporation pathways. Surprisingly, about $50 \%$ of the inhabitants of one village (Muslyumovo) showed measurable body burdens of ${ }^{137} \mathrm{Cs}$. The mean value was $600 \mathrm{~Bq}$, the highest value (not used for the mean) was $10 \mathrm{kBq} \cdot{ }^{137} \mathrm{Cs}$ has an effective halflife of only 50 to 150 days and therefore indicates recent incorporations.

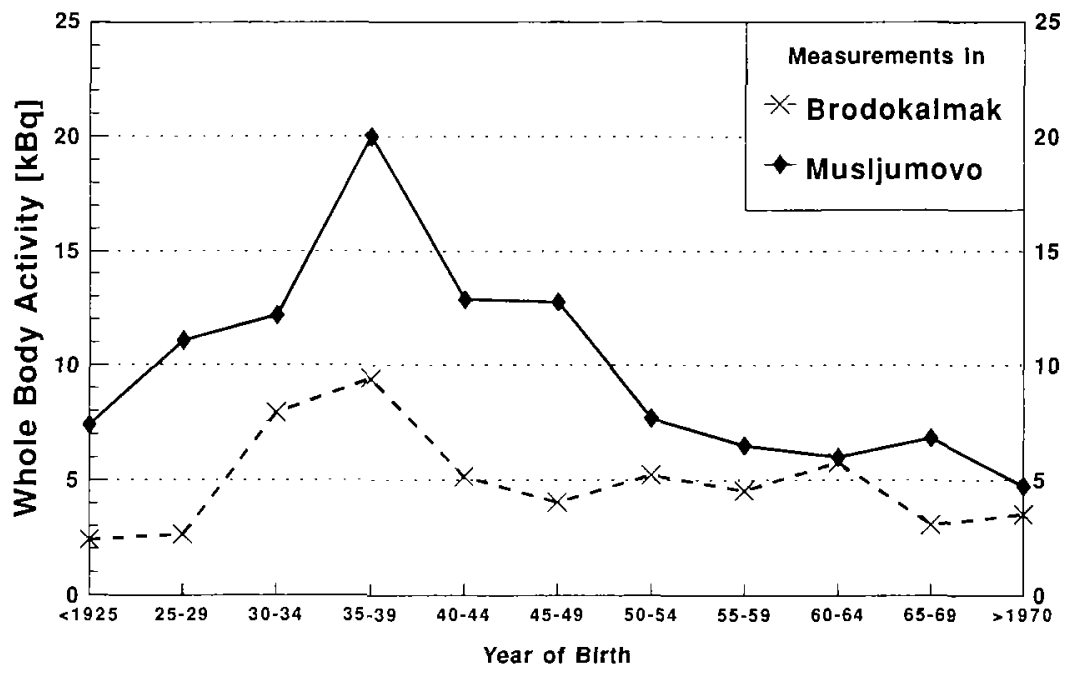

Fig. 1. - Age dependence of mean ${ }^{90}$ Sr body burdens in inhabitants of two Techa river settlements (216 and 177 measurements on females and males, respectively).

Variation en fonction de l'âge, de la charge corporelle en ${ }^{90} \mathrm{Sr}$, d'habitants de deux agglomérations de la rivière Techa (216 et 177 mesures sur des femmes et des hommes, respectivement).

\section{Contaminations and Exposures in Kazakh territories around the Polygon}

Atmospheric testing of atomic bombs was conducted between 1949 and 1962 . From a total of 118 tests, about 30 were near and at ground level leading to local fall-out. Figure 2 gives an overview of the large areas outside the Polygon with considerable cumulative external exposure from ground contaminations. 


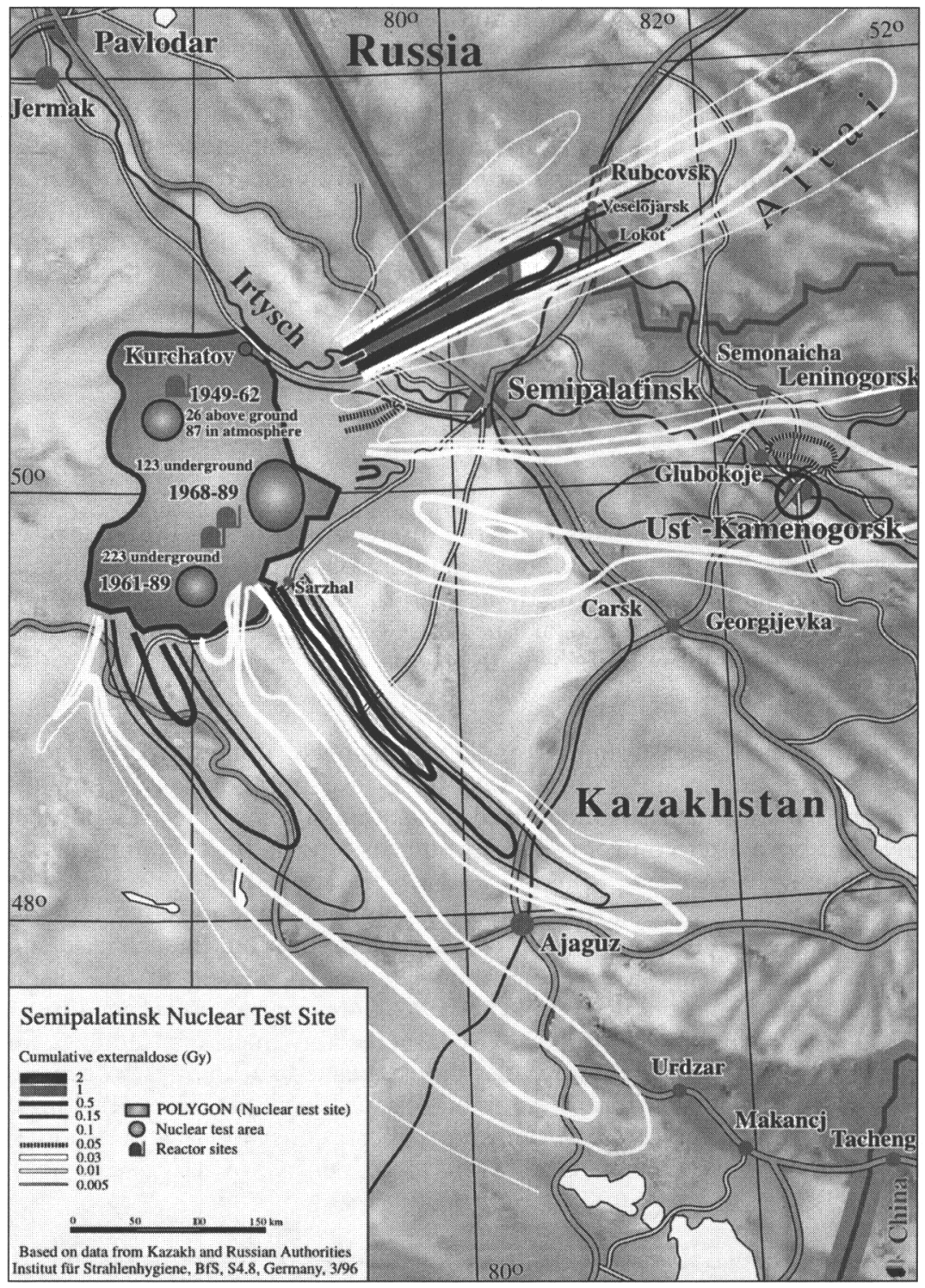

Fig. 2. - Preliminary contamination map for areas affected by ground explosions at the Polygon. Based on information from Kazakh ministries and local sources (cumulative unshielded external doses in Gy).

Carte de la contamination de zones intéressées par des explosions au sol sur le Polygone (résultats préliminaires). Sources : locales et ministères du Kazakhstan (doses externes cumulées, sans protection, Gy). 
The map is a composite of information from institutions in Semipalatinsk and from the Kazakh Ministry of Ecology with no validation performed so far. Five tests were unsuccessful and led to the local dispersion of particulate ${ }^{239} \mathrm{Pu}$. Although data on radiation and contamination's collected from the beginning of the tests was shown to the WHO mission, their completeness and availability for validation and intercomparison exercises remains to be investigated. A full assessment of past and present activities, radiation exposures and health risks to the affected population groups is hampered by the fact that primary data are stored outside the republic of Kasakhstan. However, preliminary measurements and assessments by IAEA (1994) and others (Viehweg, 1996) indicate that present levels of contamination, and therefore exposures, in the inhabited areas visited are very low.

\section{Discussion}

The good agreement of results from the intercomparisons in the area of environmental measurements and in vivo counting of ${ }^{90} \mathrm{Sr}$ indicates that the large data base available may be directly used in the assessment of the radiological situation both historically and at present. Contrary to the experience of the International Chernobyl Project there was no overestimation of $90 \mathrm{Sr}$ activities in the Russian analyses.

Environmental measurements and the grazing of domestic animals in the Techa and its floodplains indicate that fresh incorporation may occur at this time. This is confirmed by our in vivo measurements showing ${ }^{90} \mathrm{Sr}$ burdens in individuals born after control measures, such as fencing off contaminated areas and drilling wells for clean drinking water, were applied. In view of the elevated ratio of ${ }^{90} \mathrm{Sr}$ to ${ }^{137} \mathrm{Cs}$ in the Southern Urals contaminations, the ${ }^{137} \mathrm{Cs}$ body burdens found in 1993 point also to ongoing incorporation. In such case, model assumptions to transfer today's ${ }^{90} \mathrm{Sr}$ body burdens, believed to be caused by historical contamination from 1948 to 1952 only, into cumulative doses will overestimate radiation exposures by a large factor. Such confounders might considerably impair the potential of well-established techniques to contribute to dose reconstruction. More direct methods such as ESR dosimetry on teeth or FISH to quantify stable chromosome aberrations are less dependent on assumption about behaviour but they are too expensive for large scale application in cohorts.

Recent preliminary assessments in the vicinity of the Polygon, the early Soviet site for atmospheric tests, indicate contaminations in inhabited areas which are clearly higher than in the inhabited areas affected by the Nevada test site. Information is very sketchy and sometimes contradictory. From the fallout pattern of long-lived fission products and actinides, a retrospective external dose assessment for the local population living in the affected areas during the time of the tests might be feasible. The potentially very important contributions from inhalation and ingestion of critical fission radionuclides, such as ${ }^{90} \mathrm{Sr}$ 
and 131 I, can only be elucidated through the reconstruction of important food chains and life styles. In worst case scenarios, the nomadic life of the rural population with its heavy reliance on fresh milk and milk products might have caused high doses in infants for the thyroid gland from $131 \mathrm{I}$ and for bone marrow from ${ }^{90} \mathrm{Sr}$. Acute doses from actinides such as plutonium and ${ }^{241} \mathrm{Am}$ are considered to be small.

Despite the large environmental problems remaining, it is important to state that human exposures were contracted mainly during the first days to months after the fall-out and therefore are mainly historical. Localised problem areas remain in the Polygon in the vicinity of crater lakes created by ground and shallow underground explosions and near ground zero localisations. Whether radioactivity spreading from underground tests through local ground water aquifers to man and agriculture poses a potential radiological threat has still to be elucidated.

Many of the information needed to estimate past, present and potential future health detriment from the atmospheric bomb tests in the Polygon area is either lacking or not available to local health care institutions. Analyses might be based on indirect methods, such as theoretical considerations relying on dose estimates and risk coefficients for important health effects such as cancer, teratogenic and genetic effects. Such an assessment would have to be built from available information on exposure and on retrospective dose reconstruction. Whether the radiological risks already are or will be showing in the health statistics of the affected regions is not resolved. This is not only a question of the size of risks but also dependent on the completeness and quality of the local health records. In view of the limited size of the strongly affected cohorts, it remains open whether hypotheses on the effects of protracted radiation doses might by answered by epidemiological studies in the Semipalatinsk area.

Contrary to the German experience of large scale ${ }^{137} \mathrm{Cs}$ in vivo counting in the vicinity of Chernobyl, where a certificate of an independent measurement, showing low ${ }^{137} \mathrm{Cs}$ body burdens, was able to alleviate psychosocial stress due to poorly understood exposures, the measurements in the Techa river valley of persons having high ${ }^{90} \mathrm{Sr}$ body burdens were sometimes negatively received. This experience revealed that an international contribution to the assessment of radiological situations in heavily exposed populations should also contain a component of humanitarian help; i.e. a direct benefit for the affected population. In other words, the improvement of individual dosimetric data has to go hand in hand with better medical services. Only such an approach provides the ethical foundation for the establishment of dosimetric and health data bases for learning as much as possible from these unique exposure situations. 


\section{RÉFÉRENCES}

Akleyev A.V. and Lyubchansky (1994) Environmental and medical effects of nuclear weapon production in the Southern Urals. In: A First Assessment of Radiation Doses and Health Effects in Workers and Communities Exposed since 1948 in the Southern Urals (W. Burkart and A. Kellerer, Eds.), Special Issue of Sci. Tot. Environ. 142, 1-8.

Degteva M.O., Kozheurov V.P. and Vorobiova M.I. (1994a) General approach to dose reconstruction in the population exposed as a result of the release of radioactive wastes in the Techa river. In: A First Assessment of Radiation Doses and Health Effects in Workers and Communities Exposed since 1948 in the Southern Urals (W. Burkart and A. Kellerer, Eds.), Special Issue of Sci. Tot. Environ. 142, 49-62.

Kozheurov V.P. (1994b) SICH-9.1: a unique whole body counting system for measuring ${ }^{90} \mathrm{Sr}$ via Bremsstrahlung: the main results from a long-term investigation of the Techa river population. In: A First Assessment of Radiation Doses and Health Effects in Workers and Communities Exposed since 1948 in the Southern Urals (W. Burkart and A. Kellerer, Eds.), Special Issue of Sci. Tot. Environ. 142, 37-48.

Romanov J.N. et al. (1991) The Kyshtym Accident: Cause, Scale and Radiation Characteristics. In: Proceedings of the Seminar on Comparative Assessment the Environmental Impact of Radionuclides Released during Three Major Nuclear Accidents: Kyshtym, Windscale, Chernobyl, Commission of the European Communities Report EUR 13574, 25.

Umweltradioaktivität und Strahlenbelastung, Jahresbericht (1991) herausgegeben vom Bundesminister für Umwelt, Naturschutz und Reaktorsicherheit, Deutschland, Bonn (in German).

Wahl W., Maushart R., König K., Hornung L. and Burkart W. (1996) Combined $\beta / \gamma$ and Bremsstrahlung monitor for measurement of incorporated radionuclides: the ${ }^{90} \mathrm{Sr}$ in vivo counter. Nuclear Instru. Meth. Phys. Res. A 369, 693-697.

Winkelmann I., Romanov G.N., Goloshapov P., Burkart W., Gesewski P., Mundigl S., Buchröder H., Thomas M. and Brummer Ch. (1997) A first intercomparison and validation exercise in Southern Urals areas contaminated by releases into Techa river and by the Kyshtym fallout. Health Phys., submitted.

UNSCEAR Report (1993) United Nations Scientific Committee on the Effects of Atomic Radiation. Sources and Effects of Ionizing Radiation. UNSCEAR 1993 Report, Wien.

Stegnar P. (1994) Present Radiological Situation at the Semipalatinsk Nuclear Test Site. Presented at the NATO Advanced Research Workshop on Long-term Consequences of Nuclear Tests, Barnaul, Siberia, September 1994.

Viehweg M. (1996) Abschlußbericht zum Projekt, "Vorstudie zur radioökologischen Bewertung des ehemaligen Kernwaffentestgebietes Semipalatinsk in der Republik Kasachstan", Chemnitz (1996), internal report in German. 